\title{
Survey of lactic acid bacteria during the ripening of Caciocavallo cheese produced in Molise
}

\author{
Raffaele COPPOLA*, Mariantonietta SUCCI, Elena SORRENTINO, \\ Massimo IORIZZO, Luigi GRAZIA
}

Dipartimento di Scienze e Tecnologie Agroalimentari, Ambientali e Microbiologiche, Università degli Studi del Molise, Via De Sanctis, 86100 Campobasso, Italy

(Received 5 January 2001; accepted 10 December 2002)

\begin{abstract}
The microbiology of raw milk, traditionally-made Caciocavallo cheese from Molise was studied throughout ripening. Three different media (MRS agar, MRS agar at pH 5.4 and LBS) and four different incubation temperatures $\left(15,22,28\right.$ and $\left.45^{\circ} \mathrm{C}\right)$ were used for lactobacilli, and M17 agar and Slanetz \& Bartley medium were used for cocci with the aim of obtaining a complete view of the evolution of these microbial groups. The overall microbiological quality of the product was quite satisfactory; enterobacteria were already absent at $36 \mathrm{~h}$ following shaping. High counts of lactic acid bacteria were found in the cheese through the 3 months of ripening. The microbial population present from day 1 of ripening consisted essentially of mesophilic lactic acid bacteria, predominantly lactobacilli, which gradually obtained the advantage over the thermophilic strains. The predominant species were as follows: Lactobacillus paracasei subsp. paracasei, Lb. pentosus, $L b$. coryneformis subsp. torquens, Lb. plantarum and $L b$. brevis together with $L b$. casei, Lb. mali, $L b$. rhamnosus, $L b$. sakei and $L b$. coryneformis subsp. coryneformis. The thermophilic lactic acid bacteria could be ascribed to Lactobacillus helveticus, Lb. delbrueckii subsp. bulgaricus, Lb. delbrueckii subsp. lactis and Lb. delbrueckii subsp. delbrueckii. Lactococci were either Lc. lactis subsp. lactis or Lc. plantarum and enterococci were E. faecalis or E. faecium.
\end{abstract}

\section{Caciocavallo / raw milk cheese / microbiology / ripening}

Résumé - Vue d'ensemble sur les bactéries lactiques pendant l'affinage du fromage Caciocavallo produit dans le Molise. Nous avons suivi les changements microbiologiques au cours de l'affinage du fromage "Caciocavallo" produit avec du lait cru dans des zones de production traditionnelle de la région Molise. Des niveaux élevés en bactéries lactiques ont été relevés jusqu'à environ 3 mois d'affinage. Trois milieux différents (MRS agar, MRS agar acidifié à pH 5,4 et LBS) incubés à quatre températures d'incubation $\left(15,22,28\right.$ et $\left.45^{\circ} \mathrm{C}\right)$ ont été utilisés pour avoir une vue d'ensemble de la flore lactique du fromage. La qualité microbiologique globale du produit était satisfaisante. En effet, dès 36 heures on a constaté l'absence d'entérobactéries. Dès les premiers jours de la maturation la microflore lactique présente correspondait essentiellement à des bactéries lactiques mésophiles (surtout des lactobacilles) qui avaient pris graduellement le dessus sur les micro-organismes thermophiles. Parmi les lactobacilles mésophiles isolés, les espèces les plus représentées étaient: Lactobacillus paracasei subsp. paracasei, Lb. pentosus, Lb. coryneformis subsp. torquens, Lb. plantarum et $L b$. brevis ainsi que Lb. casei, Lb. mali, Lb. rhamnosus, Lb. sakei

* Correspondence and reprints

Tel.: +390874404607; fax: +390874404652; e-mail: coppola@ unimol.it 
et $L b$. coryneformis subsp. coryneformis. Les bactéries lactiques thermophiles ont pu être identifiées comme Lb. helveticus, Lb. delbrueckii subsp. bulgaricus, Lb. delbrueckii subsp. lactis et Lb. delbrueckii subsp. delbrueckii, les lactocoques comme Lc. lactis subsp. lactis et Lc. plantarum et les entérocoques comme $E$. faecalis et $E$. faecium.

\section{Fromage au lait cru / Caciocavallo / microbiologie / affinage}

\section{INTRODUCTION}

Many cheese varieties, though probably unheard of outside their specific areas of production, are indeed made and consumed within these well-defined locations. As economic and environmental conditions change within a given region, the art of making some cheeses can be lost, particularly when it is a farmhouse-type cheese, as the manufacturing procedures are not well described in the literature [14].

In southern Italy there is a wide variety of fresh and ripened pasta filata cheeses. Among the many types, Caciocavallo distinguishes itself as a ripened pasta filata cheese manufactured by almost the same technological processes as those employed for Provolone cheese. Variations can be noted between the different types of Caciocavallo produced in different areas. Caciocavallo from Molise, especially the home-style varieties produced in various locations throughout the region, represents a fine example of typical production, meriting protection and valorisation not only for its superb quality but also for its economic value as it is widely consumed nationally and is gradually becoming appreciated world-wide. In 1993, Italian legislation established the "Caciocavallo Silano" denomination. In 1996 it was recognised as a DOP (Protected Origin Denomination) product under the auspices of the European Community. These provisions, however, unified the different varieties to represent a single typical cheese.

The manufacturing technology of Caciocavallo from Molise has been described elsewhere [6]. Typical Molisan Caciocavallo is made locally throughout the year from milk produced by dairy cows that are generally grazed. The cheese is obtained by coagulation of whole raw cow milk, at a natural $\mathrm{pH}$, to which natural whey starter and liquid calf rennet is added. It is cooked and manually stretched at about $85^{\circ} \mathrm{C}$ and is salted but not subjected to a smoking process; it is ripened either for a brief time (up to 3 months), a period characterised by proteolysis, or it is slowly ripened (up to 12 months), characterised by proteolytic-lipolytic activity. However, the greater part of the products is consumed within 3 months of ripening.

Preparation of the natural whey starter used in its production is fundamentally analogous to what has been reported elsewhere. It is a culture of bacteria, most of which are acid producers, obtained from whey of the previous day's cheese-making and incubated at room temperature [25].

The microbiological characteristics of the starter cultures used in the transformation of milk to pasta filata cheese of both short and long maturation have been studied in depth [3, 25]. However, little is known about the microorganisms involved in the ripening stages of the cheeses. It has, in fact, been too often surmised that a very mature cheese product is affected essentially by the quality of the starter employed and only marginally by microbial activity of the bacteria eventually present during the ripening period. Such conjectures were based on the belief that the conditions of the cheese, after the initial stages of ripening, completely thwarted microbial growth and survival. This theory was particularly thought to be applicable to cooked cheeses, and even more so, to stretched cheeses, since it was based on the presumption that cooking and stretching temperatures drastically reduce the microbial population. 
Recent studies carried out on Parmigiano Reggiano cheese showed the presence of noticeable counts of lactic acid bacteria until the end of the ripening period $[4,5$, $18]$.

Based on the reasons discussed above, we sought to investigate the presence of lactic acid bacteria during ripening of Caciocavallo from Molise produced with traditional dairy-farm technologies in order to obtain an overview of the density of counts and to identify the particular species of lactic acid bacteria present.

\section{MATERIALS AND METHODS}

\subsection{Samples}

Three different cheese-making trials were monitored in a farmhouse-style dairy plant in the province of Isernia. Based on information collected from a survey of the entire manufacturing territory, this dairy factory was chosen for its "typical" technological processes and use of raw milk for cheese-making, which are representative of the manufacturing techniques and conditions of small establishments in the region. Whole Caciocavallo cheeses, taken from the same production run, were marked and ripened after shaping and salting. The various samples were collected $36 \mathrm{~h}$ after stretching and at 7, 14, 20, 30, 40 and $85 \mathrm{~d}$ of ripening. They were transported to the laboratory in portable refrigerators within $2 \mathrm{~h}$.

Ten $g$ from the central portion of each cheese were extracted aseptically and homogenised with $90 \mathrm{~mL}$ of sterile $1 / 4$ Ringer's solution in a blender (Stomacher 400, Seward Medical, London, UK). Tenfold dilutions were made in the same diluent. All samples were pour plated in duplicate.

\subsection{Media and growth conditions}

Lactic acid bacteria were counted by pour plating in MRS agar (Oxoid, Basingstoke, UK), MRS agar pH 5.4 and LBS
(BBL, Cockeysville, MD, USA) after anaerobic incubation (BBL Gaspack System) at $15^{\circ} \mathrm{C}$ for $10 \mathrm{~d}, 22^{\circ} \mathrm{C}$ for $72 \mathrm{~h}$, $28^{\circ} \mathrm{C}$ for $72 \mathrm{~h}$ and $45^{\circ} \mathrm{C}$ for $48 \mathrm{~h}$.

Thermophilic streptococci were counted in M17 agar (Oxoid) after incubation for $72 \mathrm{~h}$ at $45^{\circ} \mathrm{C}$. Presumptive lactococci were counted in M17 agar (Oxoid) after incubation for $72 \mathrm{~h}$ at $22^{\circ} \mathrm{C}$. Enterococci were counted in Slanetz \& Bartley medium (Oxoid) after incubation for $48 \mathrm{~h}$ at $37^{\circ} \mathrm{C}$. Enterobacteriaceae were counted in Violet Red Bile Glucose Agar (Oxoid) after incubation for $24 \mathrm{~h}$ at $37^{\circ} \mathrm{C}$.

Five colonies showing different morphologies were randomly picked from each 25-50 colony count plate of MRS, MRS pH 5.4 and LBS incubated at the four different temperatures and of M17 at 22 and $45{ }^{\circ} \mathrm{C}$ and Slanetz \& Bartley medium. Purified strains were classified according to the references $[9,13,23]$.

All strains were maintained at $4{ }^{\circ} \mathrm{C}$ as deep cultures in semisolid $(0.45 \%$ agar $)$ MRS agar supplemented with $0.6 \%$ $\mathrm{CaCO}_{3}$. All isolates were tested for morphology, Gram-reaction and catalase.

\subsubsection{Lactobacilli}

Gas production from glucose was determined in MRS broth without citrate containing inverted vials (Durham). Amygdalin, arabinose, arbutin, cellobiose, fructose, galactose, glucose, gluconate, inulin, lactose, maltose, mannitol, mannose, melezitose, melibiose, ribose, rhamnose, 2-ketogluconate, n-acetylglucosamine, raffinose, salicin, sorbitol, sucrose, trehalose and xylose fermentations were determined by adding the filter-sterilised test substances to the autoclaved basal medium (MRS broth without glucose, citrate and meat extract but with $40 \mathrm{mg} \cdot \mathrm{L}^{-1}$ bromocresol purple). Tubes were incubated at $22{ }^{\circ} \mathrm{C}$ or $45^{\circ} \mathrm{C}$ for $10 \mathrm{~d}$ and observed after 3,6 and $10 \mathrm{~d}$. Arginine hydrolysis was tested in MRS broth without glucose and meat extract but containing $3 \mathrm{~g} \cdot \mathrm{L}^{-1}$ arginine 
and $2 \mathrm{~g} \cdot \mathrm{L}^{-1}$ sodium citrate replacing ammonium citrate. Ammonia was detected using Nessler's reagent. Aesculin hydrolysis was determined using the method of Sharpe et al. [22]. The lactic acid isomer was determined in MRS broth using the kits provided by Boehringer-Mannheim (Darmstadt, Germany) (L and D-lactate dehydrogenase). Growth at $15^{\circ} \mathrm{C}$ and $45^{\circ} \mathrm{C}$ for $7 \mathrm{~d}$ was examined in MRS broth. Acetoin production was determined in MRS broth using the Voges-Proskauer test at $28^{\circ} \mathrm{C}$ and $45^{\circ} \mathrm{C}$ for $48 \mathrm{~h}$.

In addition, the strains were examined for acid production $(\mathrm{pH})$ in MRS broth and in skim milk after incubation at 15, 28 and $45{ }^{\circ} \mathrm{C}$ for $15 \mathrm{~d}$.

\subsubsection{Lactococci}

Growth at 10 and $40{ }^{\circ} \mathrm{C}$, in the presence of 40 and $65 \mathrm{~g} \cdot \mathrm{L}^{-1} \mathrm{NaCl}$ was determined after $7 \mathrm{~d}$. Galactose, lactose, maltose, melezitose, melibiose, raffinose and ribose fermentation was determined at $22{ }^{\circ} \mathrm{C}$ up to $7 \mathrm{~d}$ as previously described for lactobacilli. Arginine hydrolysis was also tested as well as for lactobacilli.

Pulsed-field gel electrophoresis (PFGE) was also performed in order to confirm the identification of lactococci by detection of specific bands. The preparation of genomic DNA was performed by the method originally described by Schwartz and Cantor [21], modified as outlined by Mc Clelland et al. [16]. Restriction enzyme digestion with Sma I (Promega, Madison, USA) was performed following the manufacturer's instructions. DNA restriction fragments were separated in $1 \%$ agarose in $0.5 \mathrm{X}$ TBE using a CHEF DR III System (Bio-Rad, Segrate, Milan, Italy) apparatus and pulse times were ramped from 5 to $60 \mathrm{~s}$ for $18 \mathrm{~h}$. The agarose gel was stained with ethidium bromide $\left(0.5 \mu \mathrm{g} \cdot \mathrm{mL}^{-1}\right)$, visualised under UV light and photographed. Restriction bands were analysed using the program Quantity One 4.0 ${ }^{\circledR}$ (Applied Math ${ }^{\circledR}$, BioRad).

\subsubsection{Enterococci}

Growth at $50{ }^{\circ} \mathrm{C}$, in the presence of $1 \mathrm{~g} \cdot \mathrm{L}^{-1}$ methylene blue, of $65 \mathrm{~g} \cdot \mathrm{L}^{-1} \mathrm{NaCl}$, in $0.04 \%$ tellurite [1], in $0.01 \%$ tetrazolium [10] and on KAA (Oxoid) was determined up to $7 \mathrm{~d}$. Arabinose, galactose, lactose, maltose, melezitose, melibiose, raffinose and ribose fermentation was determined at $37^{\circ} \mathrm{C}$ up to $7 \mathrm{~d}$ as previously described for lactobacilli. Arginine hydrolysis was also tested as well as for lactobacilli at $37{ }^{\circ} \mathrm{C}$ up to $7 \mathrm{~d}$.

\section{RESULTS}

The results represent the means of the analyses carried out on 3 different cheeses.

Numbers on the three different media at the same sampling time were generally similar. At the first sampling time a mean count of $10^{6} \mathrm{CFU} \cdot \mathrm{g}^{-1}$ at $15^{\circ} \mathrm{C}$ (Fig. 1a) was obtained. Further into the ripening phase, the numbers increased to $10^{7}$ $10^{8} \mathrm{CFU} \cdot \mathrm{g}^{-1}$ after $7 \mathrm{~d}$ ripening and to $>10^{8} \mathrm{CFU} \cdot \mathrm{g}^{-1}$ at $20 \mathrm{~d}$. All samples tested after day 20 showed a progressive decrease in microbial numbers.

The results were substantially similar at $22{ }^{\circ} \mathrm{C}$, as illustrated in Figure $1 \mathrm{~b}$. Only the first sample tested was in fact higher in MRS agar with an initial value of $10^{8} \mathrm{CFU} \cdot \mathrm{g}^{-1}$, being one logarithm higher compared with MRS agar at pH 5.4 and two logarithms higher compared with LBS. Within $7 \mathrm{~d}$, the counts on the three media gave similar values, approximately $10^{7}$ and $10^{8} \mathrm{CFU} \cdot \mathrm{g}^{-1}$ at $20 \mathrm{~d}$ ripening. From this point on, a decrease in bacterial counts was observed.

At $28^{\circ} \mathrm{C}$ (Fig. 1c), in MRS at pH 5.4, an initial microbial count of about $10^{6} \mathrm{CFU} \cdot \mathrm{g}^{-1}$ was found with an increase of about 1.5 logarithms in the second tested sample. Microbial counts remained more or less constant up to $20 \mathrm{~d}$, and then decreased in the subsequent periods of observation. Some differences were noted in MRS and 

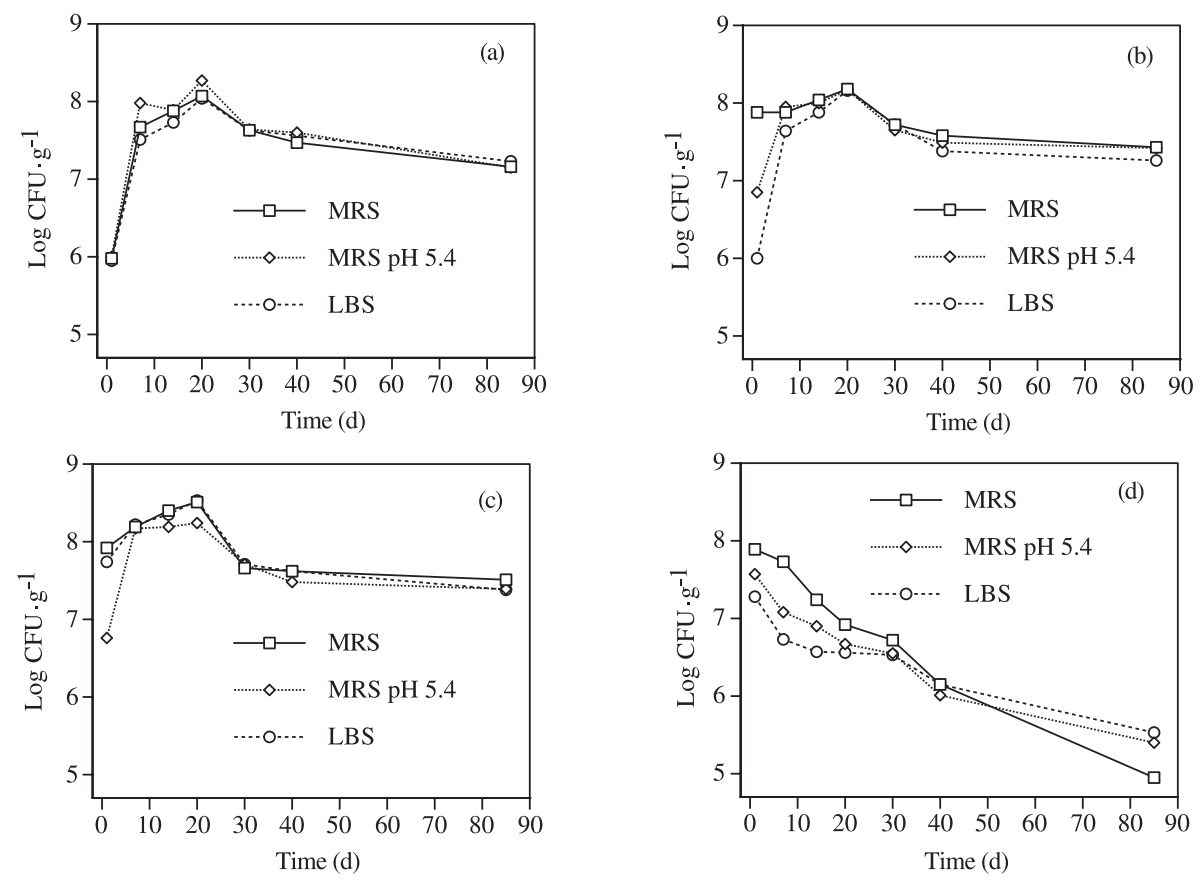

Figure 1. Changes in lactic acid bacteria counted on 3 different media after incubation at $15^{\circ} \mathrm{C}$ for $240 \mathrm{~h} \mathrm{(a),} 22^{\circ} \mathrm{C}$ for $72 \mathrm{~h} \mathrm{(b),} 28^{\circ} \mathrm{C}$ for $72 \mathrm{~h} \mathrm{(c)} \mathrm{and} 45^{\circ} \mathrm{C}$ for $48 \mathrm{~h}$ (d), during the ripening of Caciocavallo cheese (mean of results obtained on 3 different samples).

LBS, where higher counts were detected even from the first sample. These counts tended to increase further until day 20. From this point on, a reduction in counts was noted.

Counts carried out at $45^{\circ} \mathrm{C}$ (Fig. 1d) appeared to be completely different from the previous ones: the highest counts were obtained in the first sample (about 107$10^{8} \mathrm{CFU} \cdot \mathrm{g}^{-1}$ ), followed by a progressive decrease to about $10^{5} \mathrm{CFU} \cdot \mathrm{g}^{-1}$ after $85 \mathrm{~d}$.

Enterococci and thermophilic streptococci (Fig. 2) showed a decrease in number during the whole period of ripening while lactococci counts were stable. Enterobacteria gave counts less than $10 \mathrm{CFU} \cdot \mathrm{g}^{-1}$ starting from the first sampling (data not shown).

All the strains isolated at each incubation temperature from MRS, MRS pH 5.4

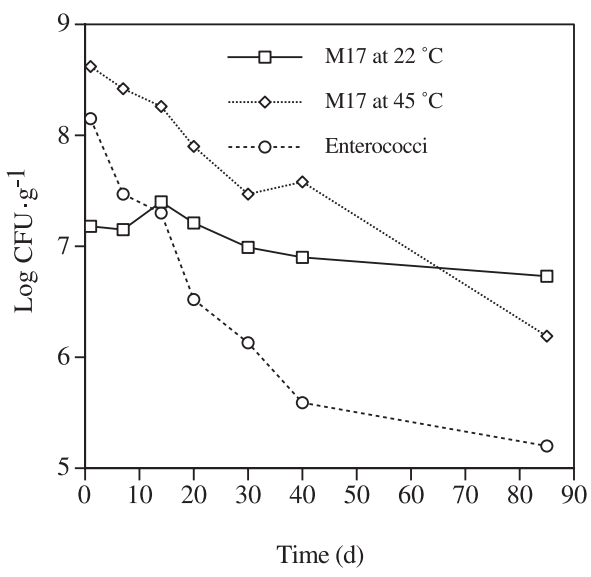

Figure 2. Changes in counts of lactic acid bacteria determined on M17 incubated at $45^{\circ} \mathrm{C}$ or at $22{ }^{\circ} \mathrm{C}$ and in counts of enterococci during the ripening of Caciocavallo cheese. 
and LBS (532 isolates) were Gram-positive and catalase-negative rods.

Among lactobacilli isolated at $45^{\circ} \mathrm{C}$ after $36 \mathrm{~h}$ ripening (45 strains), a small number (12 strains) grew at $15^{\circ} \mathrm{C}$. The majority of lactobacilli isolated from the plates incubated at each temperature (22, 28 and $45^{\circ} \mathrm{C}$ ) during the following stages of ripening were also able to grow at $15^{\circ} \mathrm{C}$. The results of the identification of lactobacilli are reported in Tables I and II. 532 strains of lactobacilli were isolated. Out of a total of 347 isolates identified, 111 were ascribed to Lactobacillus paracasei subsp. paracasei, 25 to $L b$. coryneformis subsp. torquens, 36 to $L b$. pentosus, 20 to $L b$. plantarum, 12 to $L b$. casei, 3 to $L b$. rhamnosus, 4 to Lb. mali, 3 to Lb. sakei, 2 to $L b$. coryneformis subsp. coryneformis, 16 to $L b$. brevis, 90 to Lb. helveticus, 17 to $L b$. delbrueckii subsp. bulgaricus, 5 to $L b$. delbrueckii subsp. lactis and 3 to $\mathrm{Lb}$. delbrueckii subsp. delbrueckii. The large majority of Lb. brevis strains (15 out of 16 isolates) was unable to ferment lactose. MRS and LBS generally allowed us to isolate lactobacilli at higher dilutions.

The acid production capacity of 347 isolates of lactobacilli after $15 \mathrm{~d}$ incubation in MRS broth and in skim milk is reported in Figure 3 . At $15{ }^{\circ} \mathrm{C}$ approximately $80 \%$ of the strains were capable of lowering the $\mathrm{pH}$ of MRS to 3.5-4.5 (from an original $\mathrm{pH}$ of 6.0-6.2). At $28^{\circ} \mathrm{C}$ the situation was similar to that observed at $15{ }^{\circ} \mathrm{C}$ : once more, about $80 \%$ of the isolates showed a strong acidifying capacity by lowering the $\mathrm{pH}$ to $3.5-4.0$, while the remaining $20 \%$ were able to lower $\mathrm{pH}$ in a $4.0-5.0$ range. At $45^{\circ} \mathrm{C}$ a wide variation of behaviour was noted: approximately $40 \%$ of the strains were able to acidify the substrate, reaching levels from 3.5 to $4.5 ; 20 \%$ had an intermediate acid production capacity and the remaining $40 \%$ a moderate acidifying capacity with $\mathrm{pH}$ levels falling within 5.0 to 6.0. The behaviour of isolates in skim milk at the different temperatures was similar.
All strains isolated from M17 agar plates at $22{ }^{\circ} \mathrm{C}$ were lactococci (Tab. III) and all strains isolated from the same medium at $45{ }^{\circ} \mathrm{C}$ were thermophilic streptococci. Lactococci isolated during the ripening of Caciocavallo cheese were also identified (Tab. III): among the 95 strains isolated, 84 were ascribed to Lc. lactis subsp. lactis and 11 to Lc. plantarum. Pulsed-field gel electrophoresis allowed us to confirm the identification of lactococci (data not shown).

Among the 74 enterococci isolated, 63 strains were ascribed to E. faecalis and 11 to E. faecium (Tab. IV).

\section{DISCUSSION}

The ripening process of Caciocavallo is dominated by lactic acid bacteria, mostly represented by mesophilic lactobacilli and, to a lesser extent, lactococci, which obtain the advantage over the thermophilic strains during the course of ripening.

In fact, the large majority of the strains isolated during the ripening of the cheese was able to grow at $15^{\circ} \mathrm{C}$. In addition, counts performed at $15^{\circ} \mathrm{C}$ allowed us to observe a slight increase after $7 \mathrm{~d}$ of ripening.

Thermophilic lactic acid bacteria generally represent the main microbial constituent of natural whey cultures used as starters in the production of both short and long ripened cheeses. The use of this starter is relatively widespread; it is used to make fresh and ripened stretched cheeses in addition to Parmigiano Reggiano and Grana Padano as well as a number of other cheeses $[3,5$, 20, 25].

By contrast, mesophilic lactic acid bacteria, which progressively thrive in the cheese starting from the very first moments of ripening and which reach a maximum count in 1-month-old cheese, are not a recurring component of starter cultures. With regard to the conditions that can favour the growth of these microorganisms, it is relevant to note, as it is has been in the literature thus far $[7,8,17,19]$, that 


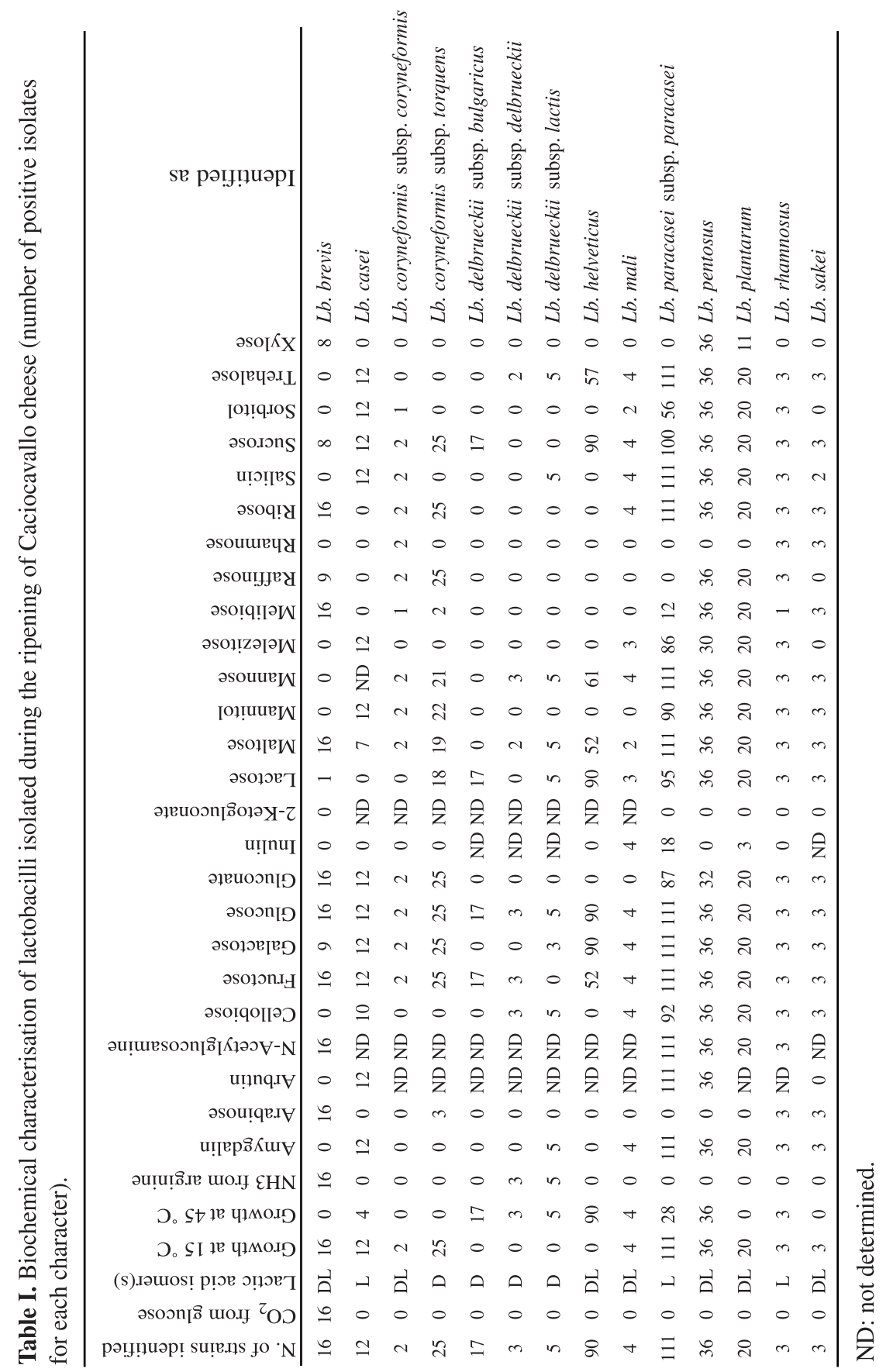




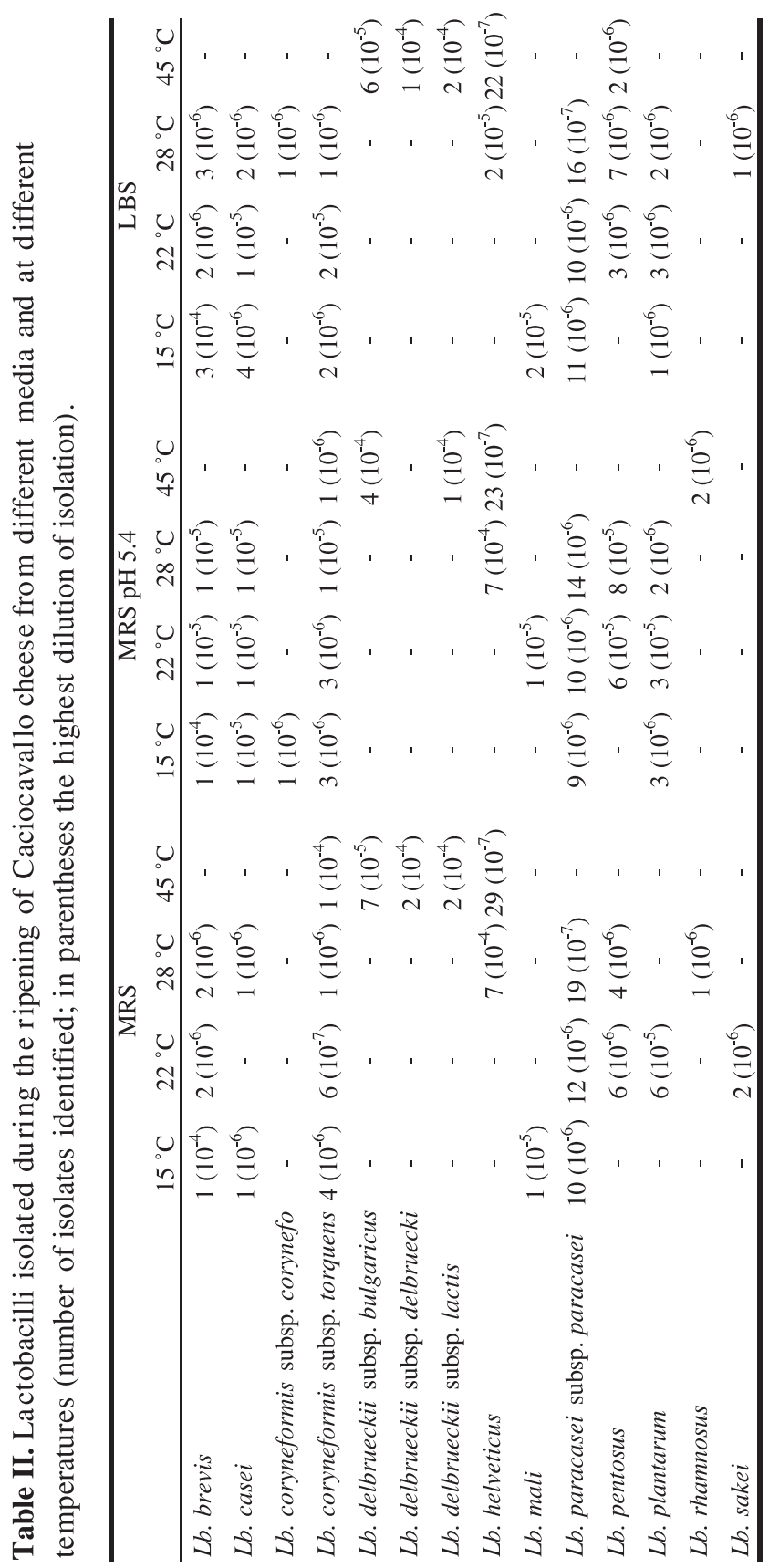



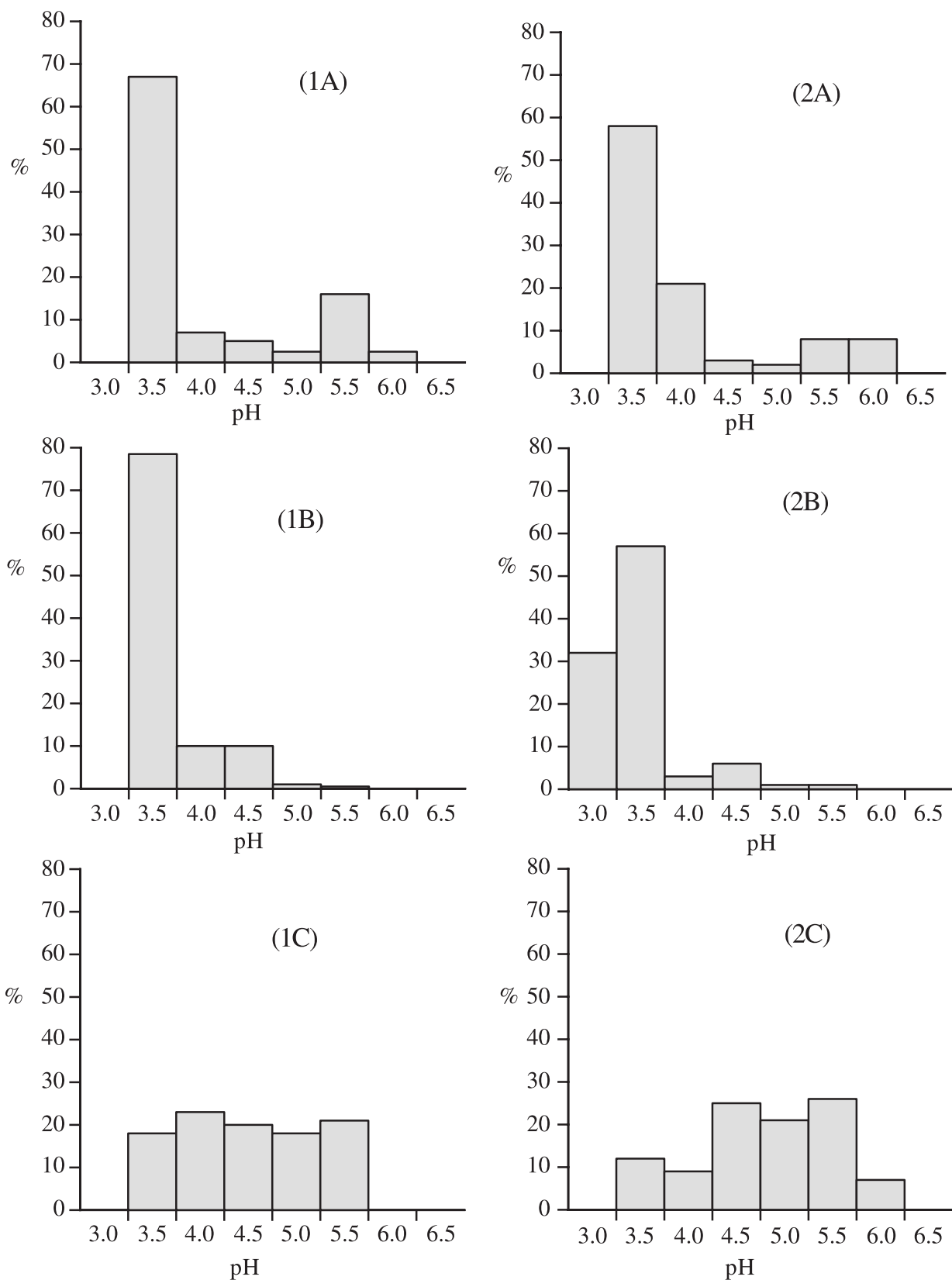

Figure 3. pH values detected in MRS broth (1) and in skim milk (2) inoculated with 347 strains of lactic acid bacteria isolated during the ripening of Caciocavallo cheese and incubated for $15 \mathrm{~d}$ at $15^{\circ} \mathrm{C}(\mathrm{A}), 28^{\circ} \mathrm{C}(\mathrm{B})$ or $45^{\circ} \mathrm{C}(\mathrm{C})$. 
Table III. Biochemical characterisation of strains isolated from M17 incubated at $22{ }^{\circ} \mathrm{C}$ during the ripening of Caciocavallo cheese.

\begin{tabular}{lcc}
\hline Identified as & Lc. lactis subsp. lactis & Lc. plantarum \\
\hline N. of strains & 84 & 11 \\
Lactic acid isomer(s) & $\mathrm{L}$ & $\mathrm{L}$ \\
Growth at $10^{\circ} \mathrm{C}$ & + & + \\
Growth at $40{ }^{\circ} \mathrm{C}$ & + & + \\
Growth in $4 \% \mathrm{NaCl}$ & + & + \\
Growth in $6.5 \% \mathrm{NaCl}$ & - & - \\
Arginine hydrolysis & + & - \\
Galactose & + & - \\
Lactose & + & - \\
Maltose & + & + \\
Melibiose & - & - \\
Melizitose & - & + \\
Raffinose & - & - \\
Ribose & + & - \\
\hline
\end{tabular}

Table IV. Biochemical characterisation of enterococci isolated during the ripening of Caciocavallo cheese.

\begin{tabular}{lcc}
\hline Identified as & $\begin{array}{c}\text { Enterococcus } \\
\text { faecalis }\end{array}$ & $\begin{array}{c}\text { Enterococcus } \\
\text { faecium }\end{array}$ \\
\hline N. of strains & 63 & 11 \\
Lactic acid isomer(s) & $\mathrm{L}$ & $\mathrm{L}$ \\
Growth at $50{ }^{\circ} \mathrm{C}$ & + & + \\
Growth in $0.1 \%$ methylene blue & + & + \\
Growth in $6.5 \% \mathrm{NaCl}$ & + & + \\
Growth in $0.04 \%$ tellurite & + & - \\
Growth in $0.01 \%$ tetrazolium & + & + \\
Arginine hydrolysis & + & + \\
Arabinose & - & + \\
Galactose & + & + \\
Lactose & + & + \\
Maltose & + & - \\
Melibiose & - & - \\
Melizitose & - & - \\
Raffinose & - & + \\
Ribose & + & - \\
\hline
\end{tabular}

the possible presence of lactose, even in the later stages of ripening, is marked by an intense variability most probably connected to the general conditions of stretching. A prolonged stretching phase, which is car- ried out by the use of high temperature water, can actually favour a reduction in the level of sugar, whereas a briefer stretching process allows the sugar content to remain relatively unchanged. 
By taking into account results from recent studies $[4,5,12]$ it is necessary to further stress the importance of these microorganisms in the quality of the final ripened cheese product. Indeed, it is the wealth of the enzymes of mesophilic and thermophilic lactic acid bacteria that play a determining role in developing the characteristic flavour of the cheese. This peculiarity is produced by microbial growth (metabolism of microorganisms) and by a release of enzymes following autolysis of the cells $[2,11,15,24]$. Within this framework, autolysis by enterococci should also be investigated since their population gradually decreases during ripening. It is also important to note the optimal hygienic manufacturing conditions in practice for this raw milk cheese; enterobacteria rapidly disappear and are totally absent within as early as $36 \mathrm{~h}$ of ripening. This observation only helps to strengthen the protection of raw milk products by demonstrating that the use of pasteurised milk for old-aged cheese production cannot be justified since it guarantees neither product hygiene nor quality, but can instead penalise the particular morphological and sensory characteristics of this typical product. The utilisation of raw ingredients in cheese-making seems to be quite suitable as long as careful attention is paid to ensuring favourable microbiological conditions of the cheese-making. In the case of the Caciocavallo analysed in this study, the use of natural whey starter constituted mainly by lactic acid bacteria together with the technological production process that incorporates stretching in relatively high temperatures of water both help to ensure the hygienic quality of the final product.

The use of three different media (MRS agar, MRS agar at pH 5.4 and LBS) and four different incubating temperatures (15, 22, 28 and $45^{\circ} \mathrm{C}$ ) to monitor lactic acid bacteria during ripening of Caciocavallo allowed us to obtain an overview of the lactic acid microflora of this cheese. It was therefore possible to assay the validity of different methods for measuring popula- tion growth and also to isolate aciduric microorganisms. The incubation temperature $15^{\circ} \mathrm{C}$ (for $10 \mathrm{~d}$ ) was particularly useful for counting and isolating strictly mesophilic lactobacilli, while the incubation temperature $45^{\circ} \mathrm{C}$ was shown to be helpful to isolate thermotolerant mesophilic strains. In fact, many strains isolated at $45^{\circ} \mathrm{C}$ showed ability to grow at $15^{\circ} \mathrm{C}$, particularly during the ripening of the cheese. With specific regard to the identification of lactobacilli, the isolation of thermophilic strains also from LBS agar must be underlined. On the other hand, among mesophilic lactobacilli Lb. coryneformis subsp. torquens was isolated more frequently at 15 or $22{ }^{\circ} \mathrm{C}$ than at 28 or $45^{\circ} \mathrm{C}$.

Characterisation of the isolates based on growth temperatures also allowed us to ascertain that the microbial population counted at $45^{\circ} \mathrm{C}$ in the early stages of ripening was predominantly thermophilic, while the advanced stages were dominated by mesophilic strains. This result is in perfect agreement with findings from other authors regarding the presence of lactic acid bacteria in Parmigiano Reggiano during ripening $[4,5]$.

Similar conclusions can be drawn from the observations of acid production capacity of the different strains at different temperatures.

Approximately $80 \%$ of the isolates were able to grow at $15^{\circ} \mathrm{C}$ by lowering $\mathrm{pH}$ values to a level ranging from 3.5 to 4.5 . Similar behaviour was also apparent at $28{ }^{\circ} \mathrm{C}$, whereas the microbial population at $45^{\circ} \mathrm{C}$ had a more homogeneous distribution as shown in Figure 3.

Analysis of the population of lactic acid bacteria isolated allowed us to validate a constant presence of lactobacilli, among which the most predominant species were facultatively heterofermentative lactobacilli.

\section{REFERENCES}

[1] Atlas R.M., Handbook of Microbiological Media for the Examination of Food, CRC Press Inc., Boca Raton, Florida, USA, 1995. 
[2] Chapot-Chartier M.M., Les autolysines des bactéries lactiques, Lait 76 (1996) 91-109.

[3] Coppola S., Parente E., Dumontet S., Peccerella A., The microflora of natural whey cultures utilized as starters in the manufacture of Mozzarella cheese from water buffalo milk, Lait 68 (1988) 295-310.

[4] Coppola R., Nanni M., Iorizzo M., Sorrentino A., Sorrentino E., Grazia L., Survey of lactic acid bacteria isolated during the advanced stages of the ripening of Parmigiano Reggiano cheese, J. Dairy Res. 64 (1997) 305-310.

[5] Coppola R., Nanni M., Iorizzo M., Sorrentino A., Sorrentino E., Chiavari C., Grazia L., Microbiological characteristics of Parmigiano Reggiano cheese during the cheesemaking and the first months of the ripening, Lait 80 (2000) 479-490.

[6] Cubadda R., Colavita G., Coppola R., Molise Caciocavallo, in: Lembo P., Spedicato E. (Eds.), Cnr - I Prodotti Caseari del Mezzogiorno, Grafiche Valdacca, Vignate, Milano, Italy, 1992, pp. 233-235.

[7] Cubadda R., Colavita G., Coppola R., Molise Caciocavallo, in: Lembo P., Spedicato E. (Eds.), Cnr - I Prodotti Caseari del Mezzogiorno, Grafiche Valdacca, Vignate, Milano, Italy, 1996, pp. 255-258.

[8] De Leo P., Lovino R., Leone A.M., Di Benedetto F.V., Alviti F., Gambacorta G., Pallavicini C., Alloggio V., Caponio F., De Leonardis A., Puglia - Caciocavallo, in: Lembo P., Spedicato E. (Eds.), Cnr - I Prodotti Caseari del Mezzogiorno, Grafiche Valdacca, Vignate, Milano, Italy, 1996, pp. 233-236.

[9] Devriese L.A., Collins M.D., Wirth R., The genus Enterococcus, in: Balows A., Trüper H.G., Dworkin M., Harder W., Schleifer K.H. (Eds.), The Prokaryotes, Springer-Verlag Inc., New York, USA, 1992, pp. 1465-1481.

[10] Devriese L.A., Pot B., Damme L.V., Kersters K., Haesebrouck F., Identification of Enterococcus species isolated from foods of animal origin, Int. J. Food Microbiol. 26 (1995) 187-197.

[11] El-Kholy W., El-Soda M., Ezzat N., El Shafei H., Autolysis and intracellular enzymes release from cheese related dairy lactobacilli, Lait 78 (1998) 439-452.

[12] Giraffa G., Mucchetti G., Addeo F., Neviani E., Evolution of lactic acid microflora during Grana cheese-making and ripening, Microbiol. Alim. Nutr. 15 (1997) 115-122.

[13] Hammes W.P., Weiss N., Holzapfel W., The genera Lactobacillus and Carnobacterium, in: Balows A., Trüper H.G., Dworkin M., Harder W., Schleifer K.H. (Eds.), The Pro- karyotes, Springer-Verlag Inc., New York, USA, 1992, pp. 1534-1594.

[14] Licitra G., Portelli G., Campo P., Longobardo G., Farina G., Carpino S., Barbano D.M., Technology to produce Ragusano cheese: A survey, J. Dairy Sci. 81 (1998) 3343-3349.

[15] Lortal S., Rousseau M., Boyaval P., van Heijenoort J.V., Cell wall and autolytic system of Lactobacillus helveticus ATCC 12046, J. Gen. Microbiol. 137 (1991) 549-559.

[16] Mc Clelland M., Jones R., Patel Y., Nelson M., Restriction endonucleases for pulsed field mapping of bacterial genomes, Nucl. Acid Res. 15 (1987) 5985-6005.

[17] Mincione B., Caridi A., Fuda S., Calabria Caciocavallo, in: Lembo P., Spedicato E. (Eds.), Cnr - I Prodotti Caseari del Mezzogiorno, Grafiche Valdacca, Vignate, Milano, Italy, 1996, pp. 63-66.

[18] Nanni M., Coppola R., Iorizzo M., Sorrentino A., Sorrentino E., Grazia L., Lactic acid bacteria during the ripening of ParmigianoReggiano, Sci. Tecn. Latt. Casearia 48 (1997) 211-216.

[19] Russo C., Fichera G., Gattuso A.M., Arcoleo G., Candido A., Indovina M.C., Pirrone L., Rotolo G., Seminerio V., Sicilia - Caciocavallo, in: Lembo P., Spedicato E. (Eds.), Cnr - I Prodotti Caseari del Mezzogiorno, Grafiche Valdacca, Vignate, Milano, Italy, 1996, pp. 541-544.

[20] Sacchetti M., Zambonelli C., Acidità e carico microbico nei sieri-innesto della zona tipica del "Parmigiano-Reggiano", Latte 37 (1963) 351-360.

[21] Schwart D.C., Cantor C.R., Separation of yeast chromosome-sized DNAs by pulsed field gradient gel electrophoresis, Cell 37 (1984) 67-75.

[22] Sharpe M.E., Fryer T.F., Smith D.G., Identification of the lactic acid bacteria, in: Gibbs B.M., Skinner F.A. (Eds.), Identification methods of Microbiologist, Academic Press, London, UK, 1966, p. 72.

[23] Teuber M., Geis A., Neve H., The genus Lactococcus, in: Balows A., Trüper H.G., Dworkin M., Harder W., Schleifer K.H. (Eds.), The Prokaryotes, Springer-Verlag Inc., New York, USA, 1992, pp. 1482-1501.

[24] Valence F., Lortal S., Zymogram and preliminary characterization of Lactobacillus helveticus autolysins, Appl. Environ. Microbiol. 65 (1995) 3391-3399.

[25] Villani F., Pepe O., Coppola R., Andolfi R., Coppola S., Aspetti microbiologici della fabbricazione del Caciocavallo podolico, Latte 16 (1991) 780-788. 